Check for updates

Cite this: Chem. Sci., 2019, 10, 1368

๑ All publication charges for this article have been paid for by the Royal Society of Chemistry

Received 5th October 2018

Accepted 4th November 2018

DOI: $10.1039 / \mathrm{c} 8 \mathrm{sc} 04436 \mathrm{~h}$

rsc.li/chemical-science

\section{Oxygen uptake in complexes related to [NiFeS]- and [NiFeSe]-hydrogenase active sites $\dagger$}

\author{
Xuemei Yang, Lindy C. Elrod, (D) Joseph H. Reibenspies, Michael B. Hall \\ and Marcetta Y. Darensbourg (D) *
}

A biomimetic study for $\mathrm{S} / \mathrm{Se}$ oxygenation in $\mathrm{Ni}(\mu-\mathrm{EPh})\left(\mu-\mathrm{SN}_{2}\right) \mathrm{Fe}$, $\left(\mathrm{E}=\mathrm{S}\right.$ or $\mathrm{Se} ; \mathrm{SN}_{2}=$ Me-diazacycloheptane$\left.\mathrm{CH}_{2} \mathrm{CH}_{2} \mathrm{~S}\right) ; \mathrm{Fe}=\left(\eta^{5}-\mathrm{C}_{5} \mathrm{H}_{5}\right) \mathrm{Fe}^{\prime \prime}(\mathrm{CO})$ complexes related to the oxygen-damaged active sites of [NiFeS]/ [NiFeSe]- $\mathrm{H}_{2}$ ases is described. Mono- and di-oxygenates (major and minor species, respectively) of the chalcogens result from exposure of the heterobimetallics to $\mathrm{O}_{2}$; one was isolated and structurally characterized to have $\mathrm{Ni}-\mathrm{O}-\mathrm{Se}_{\mathrm{Ph}}-\mathrm{Fe}-\mathrm{S}$ connectivity within a 5-membered ring. A compositionally analogous mono-oxy species was implicated by $\nu(\mathrm{CO})$ IR spectroscopy to be the corresponding $\mathrm{Ni}-\mathrm{O}-$ $\mathrm{S}_{\mathrm{Ph}}-\mathrm{Fe}-\mathrm{S}$ complex; treatment with $\mathrm{O}$-abstraction agents such as $\mathrm{P}(\mathrm{o} \text {-tolyl) })_{3}$ or $\mathrm{PMe}_{3}$ remediated the $\mathrm{O}$ damage. Computational studies (DFT) found that the lowest energy isomers of mono-oxygen derivatives of $\mathrm{Ni}(\mu-\mathrm{EPh})\left(\mu-\mathrm{SN}_{2}\right) \mathrm{Fe}$ complexes were those with $\mathrm{O}$ attachment to $\mathrm{Ni}$ rather than $\mathrm{Fe}$, a result consonant with experimental findings, but at odds with oxygenates found in oxygen-damaged [NiFeS]/[NiFeSe]$\mathrm{H}_{2}$ ase structures. A computer-generated model based on substituting ${ }^{-} \mathrm{SMe}$ for the $\mathrm{N}-\mathrm{CH}_{2} \mathrm{CH}_{2} \mathrm{~S}^{-}$sulfur donor of the $\mathrm{N}_{2} \mathrm{~S}$ suggested that constraint within the chelate hindered $\mathrm{O}$-atom uptake at that sulfur site.

\section{Introduction}

Hydrogenases are metalloenzymes that catalyze reversible $\mathrm{H}_{2}$ production from protons and electrons. Likely originating in pre-biotic ages and under a reducing atmosphere, the active sites contain iron, nickel and sulfur, along with simple diatomic ligands, $\mathrm{CO}$ and $\mathrm{CN}$, in optimal arrangements that produce superb biocatalysts found throughout nature. ${ }^{1}$ These structures offer guidance for design of molecular catalysts comprising earth abundant metals for application in electrolyzers and fuel cells. ${ }^{2,3}$ While the protein superstructures protect the biological redox centers from $\mathrm{O}_{2}$ as an oxidant that competes with protons, there is ample evidence, including protein crystal structures, of the detrimental effects of $\mathrm{O}_{2}$ invasion into the active site. Indeed the initial understanding of the [NiFeS]$\mathrm{H}_{2}$ ase was plagued with Ni-based EPR signals from various deactivated enzyme states damaged by partial oxidation or oxygenation. Vague terms such as "ready" and "unready" states, with recovery from oxygen damage on the order of seconds $v s$. hours, respectively, were adopted in attempts to express reductive (added $\mathrm{H}_{2}$ or $\mathrm{H}^{+}+\mathrm{e}^{-}$) reactivation requirements. ${ }^{4,5}$

As shown in Fig. 1 two subclasses exist for the $[\mathrm{NiFe}]-\mathrm{H}_{2}$ ase enzymes. The predominant form, [NiFeS]- $\mathrm{H}_{2}$ ase, contains a set of four cysteines around $\mathrm{Ni}$; two Cys-S bridge $\mathrm{Ni}$ to an

Texas A\&M University, Department of Chemistry, College Station, TX 77843, USA. E-mail: marcetta@chem.tamu.edu

$\dagger$ Electronic supplementary information (ESI) available. CCDC 1861574, 1861577-1861580 and 1861890. For ESI and crystallographic data in CIF or other electronic format see DOI: $10.1039 / \mathrm{c} 8 \mathrm{sc} 04436 \mathrm{~h}$
$\mathrm{Fe}^{\mathrm{II}}(\mathrm{CO})(\mathrm{CN})_{2}$ unit. A second form, $[\mathrm{NiFeSe}]-\mathrm{H}_{2}$ ase is identical to the $[\mathrm{NiFeS}]-\mathrm{H}_{2}$ ase except a terminal cysteine is replaced by selenocysteine. As the incorporation of selenocysteine requires an intricate dedicated biosynthetic machinery, as well as a high energetic cost, this form is found in few microorganisms; an example is Methanococcus voltae. ${ }^{6,7}$

Despite sharing similar active site structures, $[\mathrm{NiFeSe}]-\mathrm{H}_{2}$ ase is deemed superior to the all-sulfur, [NiFeS]- $\mathrm{H}_{2}$ ase, with respect to $\mathrm{H}_{2}$ production and $\mathrm{O}_{2}$ tolerance, the latter defined as resistance to $\mathrm{O}_{2}$ and recovery of full activity on appropriate reductive treatment. ${ }^{4,8,9}$ Fundamental differences between sulfur and selenium include the higher acidity of Se-Cys, which might account for the proton reduction disparities, while the low redox potential and high nucleophilicity of selenium in selenolates relative to sulfur in thiolates might account for the higher oxygen-tolerance of [NiFeSe] $-\mathrm{H}_{2}$ ase. ${ }^{7}$

Both the ready and unready states of $[\mathrm{NiFeS}]-\mathrm{H}_{2}$ ase are identified as containing $\mathrm{Ni}^{\mathrm{III}}$; the ready state contains a hydroxide bridge between $\mathrm{Ni}$ and $\mathrm{Fe},(\mathrm{Ni}-\mathrm{B})$, while the unready state is proposed to contain a $\kappa_{1}$-peroxide bridge or a sulfenate within a 5-membered $\mathrm{Ni}-\mathrm{O}-\mathrm{S}_{\mathrm{cys}}-\mathrm{Fe}-\mathrm{S}_{\text {cys }}$ ring $(\mathrm{Ni}-\mathbf{A})$, as depicted in Fig. 1. ${ }^{10,11}$ However, in [NiFeSe] $-\mathrm{H}_{2}$ ase, there are thus far revealed only rapid recovery or ready states comprised of oxygenates of Se- and S-cysteines; selected structures are shown in Fig. 1. ${ }^{9}$ Notably, multiple levels of oxidized chalcogenide sites, both $\mathrm{S}$ and Se, have been uncovered in [NiFeSe]- $\mathrm{H}_{2}$ ase; nevertheless the basic NiFe core structure is maintained and reductive repair is possible. As these oxygenated chalcogenides play vital roles in the reversibility of oxygen damage, small 


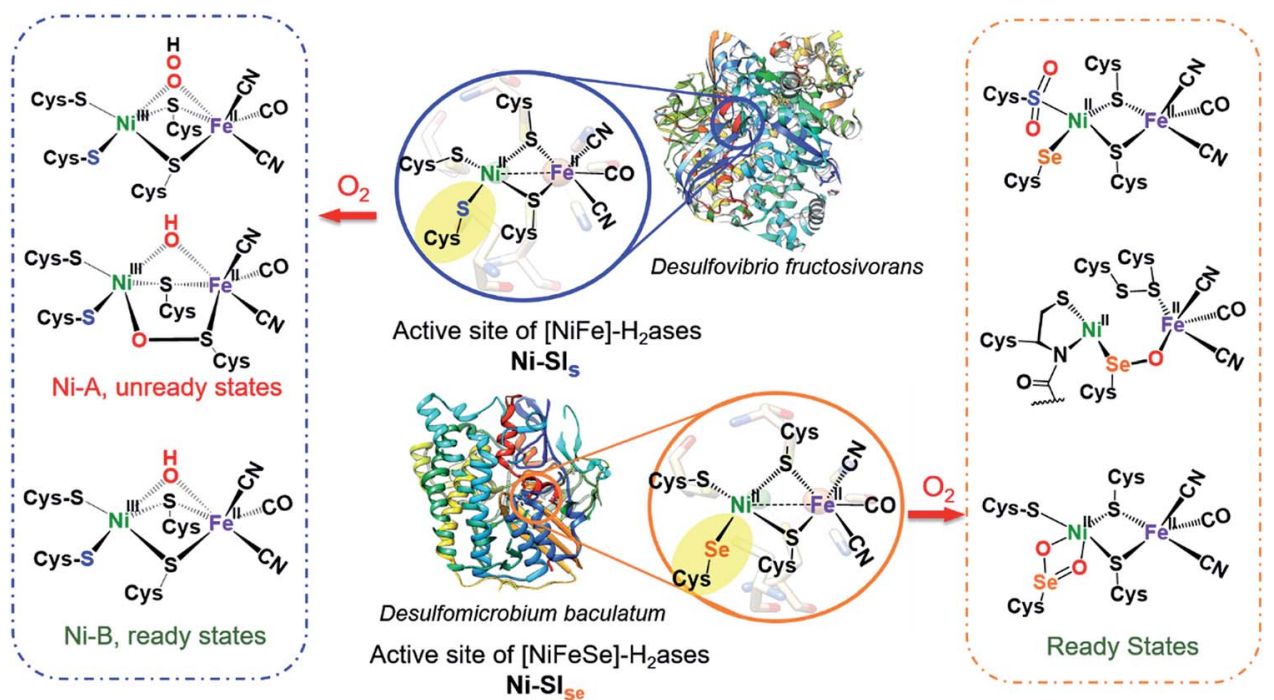

Fig. 1 Reduced (middle) active sites of [NiFe]- $\mathrm{H}_{2}$ ases and selected oxidized active sites of [NiFeS] (left) and [NiFeSe]- $\mathrm{H}_{2}$ ases (right). ${ }^{8,9,15,16}$

molecule analogues are needed to explore aerobic damage and repair, both for insight into the enzyme as well as the design of robust synthetic catalysts. Examples are limited.

Ogo, et al. isolated a high valent iron(Iv) peroxo complex on reacting solvent-coordinated complexes $\left[\mathrm{Ni}^{\mathrm{II}} \mathrm{LFe} e^{\mathrm{II}}(\mathrm{RCN})\left(\eta^{5}\right.\right.$ $\left.\mathrm{C}_{5} \mathrm{Me}_{5}\right)^{+}$with $\mathrm{O}_{2} \cdot{ }^{12-14}$ However, no oxygenated sulfur species were reported from their system. The first S-oxygenated [NiFe] complex was reported by Driess's lab as a model for sulfenate intermediates in $\mathrm{O}_{2}$-tolerant hydrogenase; it was synthesized from $\mathrm{FeBr}_{2}$ and the pre-formed sulfenato nickel complex ${ }^{17}$ rather than direct oxygenation. ${ }^{18}$

Herein, we describe a biomimetic study for S/Se oxygenation in complexes $\mathrm{Ni}(\mu-\mathrm{EPh})\left(\mu-\mathrm{SR}^{\prime}\right) \mathrm{Fe},\left(\mathrm{E}=\mathrm{S}\right.$ or Se; $\left.\mathrm{R}^{\prime}=\mathrm{N}_{2} \mathrm{~S}\right)$ with certain features of the $[\mathrm{NiFeS}] /[\mathrm{NiFeSe}]-\mathrm{H}_{2}$ ases' active sites. We report the first XRD structure of an oxygenate of selenium within a Ni-Fe complex and use it as a reference point for DFT computational analyses and predictions.

\section{Results and discussion}

Synthesis and characterizations

Nickel dithiolate complexes such as $\mathrm{NiN}_{2} \mathrm{~S}_{2}$ are well known to react as metalloligands by formation of $\mathrm{Ni}-\left(\mu_{2}-\mathrm{SR}\right)_{2}-\mathrm{M}^{\prime}$ bridges. ${ }^{19}$ Adopting a $\left[\mathrm{NiN}_{2} \mathrm{~S}\right]_{2}{ }^{2+}$ bimetallic nickel dimer ${ }^{20}$ as platform for dimer cleavage reactions, ${ }^{19,21,22}$ we have derived monomeric
$\mathrm{Ni}\left(\mathrm{N}_{2} \mathrm{~S}\right)(\mathrm{EPh})(\mathrm{E}=\mathrm{S}$ and Se, complexes $\mathbf{A}$ and $\mathbf{B}$, respectively). These cis-dichalcogenides are subsequently used as metalloligands to an iron receiver unit, $\left(\eta^{5}-\mathrm{C}_{5} \mathrm{H}_{5}\right) \mathrm{Fe}^{\mathrm{II}}(\mathrm{CO})^{+}$, in analogy to well-known $\mathrm{NiN}_{2} \mathrm{~S}_{2}$ derivatives. ${ }^{23}$ The synthetic scheme shown in Fig. 2 is further detailed (mass spectra, elemental analyses, ${ }^{1} \mathrm{H}$ and ${ }^{13} \mathrm{C}$ NMR spectra, and XRD crystal structures) in the ESI. $\uparrow$ The lower value of $\nu(\mathrm{CO})\left(1934 \mathrm{~cm}^{-1}\right)$ in the $\mathrm{NiSe}_{\mathrm{Ph}} \mathrm{Fe}^{+}$, complex 2, as contrasted to $\mathrm{NiS}_{\mathrm{Ph}} \mathrm{Fe}^{+}$, complex 1 $\left(1939 \mathrm{~cm}^{-1}\right)$, is attributed to the better electron donor properties of Se over $\mathrm{S},{ }^{7}$ resulting in better pi-backbonding from $\mathrm{Fe}^{\mathrm{II}}$ to the $\mathrm{CO}$ reporter ligand.

X-ray quality crystals of monomeric Ni complex $\mathbf{A}$ were obtained by diethyl ether vapor transfer into a solution of $\mathrm{CH}_{3} \mathrm{CN}$. Complex $B$ and the Ni-Fe complexes $\left(\mathbf{1}, 2\right.$ and $\left.\mathbf{2}^{\prime}\right)$, were crystallized from a pentane-layered $\mathrm{CH}_{2} \mathrm{Cl}_{2}$ solution at $-35{ }^{\circ} \mathrm{C}$. Polymorphs, 2 and $\mathbf{2}^{\prime}$, are distinguished by the orientation of the $\mathrm{SePh}$ planes in the $\mathrm{NiSe}_{\mathrm{Ph}} \mathrm{Fe}^{+}$complexes. Dark red needle crystals of $\mathbf{2}$ exist in a pbca space group; $\mathbf{2}^{\prime}$, as dark red blocks, is in the $P 2_{1} / c$ space group.

Molecular structures determined by XRD are unexceptional, Fig. 3. The $>3.0 \AA$ distances between $\mathrm{Ni}$ and Fe are beyond bonding. The $\mathrm{NiE}_{\mathrm{Ph}} \mathrm{Fe}^{+}$complex structures find a typical pianostool geometry exists about the $\left[\left(\eta^{5}-\mathrm{C}_{5} \mathrm{H}_{5}\right) \mathrm{Fe}(\mathrm{CO})\right]^{+}$unit, and, as usual for bridging dithiolates, butterfly-like cores are due to the lone pair-imposed steric requirement of the chalcogenide

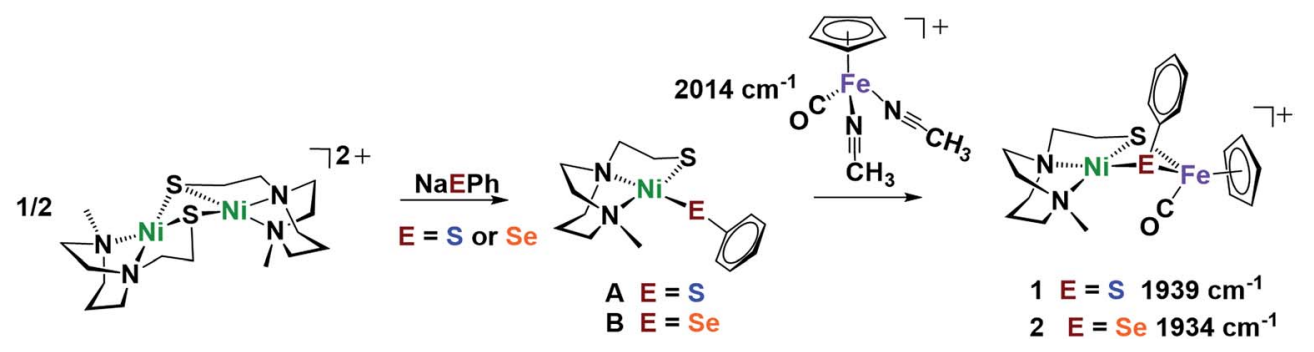

Fig. 2 Synthetic scheme for $\mathrm{NiE}_{\mathrm{Ph}} \mathrm{Fe}^{+}$complexes 1 and 2. The $\nu(\mathrm{CO})$ IR values of the products recorded in $\mathrm{CH}_{2} \mathrm{Cl}_{2}$. 


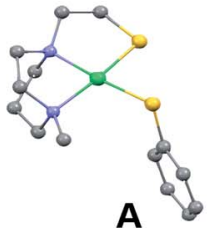

$\mathrm{Ni} \cdots \mathrm{Fe} / \AA$

$\mathrm{Ni}-\mathrm{E}_{\mathrm{Ar}} / \AA$

$\mathrm{Fe}-\mathrm{E}_{\mathrm{Ar}} / \AA$

$\angle \mathrm{Fe}-\mathrm{E}_{\mathrm{Ar}}-\mathrm{Ni}{ }^{\circ}$

$\angle \mathrm{S}-\mathrm{Fe}-\mathrm{E}_{\mathrm{Ar}}{ }^{\circ}$

$\angle \mathrm{S}-\mathrm{Ni}-\mathrm{E}_{\mathrm{Ar}}{ }^{\circ}$

$\angle \mathrm{E}_{\mathrm{Ar}}-\mathrm{Ni}-\mathrm{N}$

$\mathrm{E}_{\mathrm{Ar}}-\mathrm{C}_{\mathrm{Ph}}$

Hinge angle/ ${ }^{\circ}$

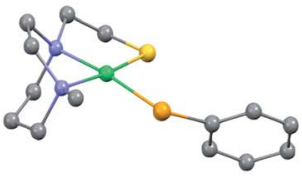

B

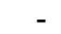

$2.309(6)$

-

-

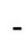

94.19(3)

93.94(8)

1.918(3)

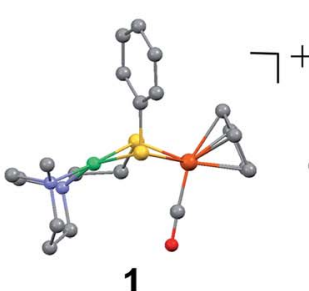

3.170

2.199(1)

2.300(2)

$89.57(5)$

$79.40(5)$

84.71(5)

101.1(1)

1.789(5)

141.15

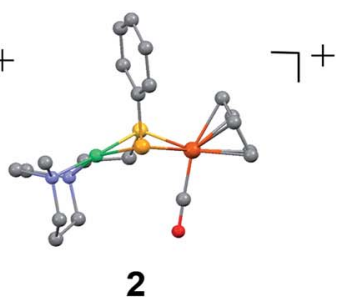

3.253

2.311(1)

2.406(1)

$87.17(4)$

79.62(5)

$84.47(6)$

101.4(2)

1.931(6)

142.69

Fig. 3 Molecular structures of $\mathrm{A}, \mathrm{B}$ and $1\left(\mathrm{NiS}_{\mathrm{Ph}} \mathrm{Fe}\right), 2$ ( $\left.\mathrm{NiSe}_{\mathrm{Ph}} \mathrm{Fe}\right)$, determined by single-crystal $\mathrm{XRD}$, with the $\mathrm{BF}_{4}{ }^{-}$ions and $\mathrm{H}$ atoms omitted. $\mathrm{E}$ in $\mathrm{A}$ and 1 is sulfur; $E$ in $B$ and 2 is selenium.

bridges. Hinge angles, defined as the intersection of the best $\mathrm{N}_{2}$ SE plane with the SEFe plane, are $c a .140-145^{\circ}$. The seleniumcontaining complexes, 2 and $2^{\prime}$ contain hinge angles slightly larger than found in $\mathbf{1 .}$

\section{Reactivity}

The chemical responsiveness of the heterobimetallic complexes was illustrated by reaction with $\mathrm{CO}(\mathrm{g})$ which, in both the $\mathrm{NiS}_{\mathrm{Ph}} \mathrm{Fe}^{+}$and $\mathrm{NiSe}_{\mathrm{Ph}} \mathrm{Fe}^{+}$complexes, resulted in Ni-Fe splitting by transferring the $\mathrm{EPh}$ to $\mathrm{Fe}$, generating $\left(\eta^{5}-\mathrm{C}_{5} \mathrm{H}_{5}\right) \mathrm{Fe}(\mathrm{CO})_{2} \mathrm{EPh}$, and returned the $\mathrm{Ni}$ to its $\left[\mathrm{NiN}_{2} \mathrm{~S}\right]_{2}{ }^{2+}$ dimeric form. On mixing complex 1 with an excess of $\mathrm{Na}^{+} \mathrm{SePh}^{-}$in $5: 1 \mathrm{CH}_{2} \mathrm{Cl}_{2} / \mathrm{MeOH}$, complex 2 is formed over the course of hours. The opposite, i.e., an attempt to replace the bridging $\mathrm{SePh}^{-}$in complex 2 by $\mathrm{SPh}^{-}$, was unsuccessful. These reactions emphasize the mobility of the $\mathrm{EPh}^{-}$unit in the $\mathrm{NiE}_{\mathrm{Ph}} \mathrm{Fe}^{+}$complex.

At $22{ }^{\circ} \mathrm{C}, \mathrm{O}_{2}$ gas was bubbled through $\mathrm{CH}_{2} \mathrm{Cl}_{2}$ solutions of heterobimetallic complexes $\mathbf{1}$ and $\mathbf{2} / \mathbf{2}^{\prime}$; the reactions were monitored by FTIR spectroscopy. The clear reddish black solution of $\mathrm{NiSe}_{\mathrm{Ph}} \mathrm{Fe}^{+}$developed into a slightly cloudy, dark red solution after $2 \mathrm{~h}$, with $\nu(\mathrm{CO})$ shifting from a sharp band at $1934 \mathrm{~cm}^{-1}$ to a broader band at $1954 \mathrm{~cm}^{-1}$, designated as complex 2+O (Fig. 4). On filtration, the mother liquor mainly contained complex $\mathbf{2}+\mathbf{O}$ and, on removal of solvent and redissolving in $\mathrm{CH}_{2} \mathrm{Cl}_{2}$, a high resolution ESI-MS ${ }^{+}$showed the parent molecular ion to have $\mathrm{m} / \mathrm{z} 552.9634$ (calc. for $[2+\mathrm{O}]^{+}, 552.9661$ ). This mono-oxygenate was isolated in $c a$. 50\% yield (Fig. S20†). The uptake of two oxygen atoms was additionally indicated by a minor signal at $m / z 568.9419$ (calc. for $[2+20]^{+}, 568.9611$ ). The

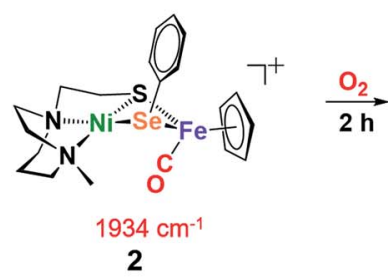

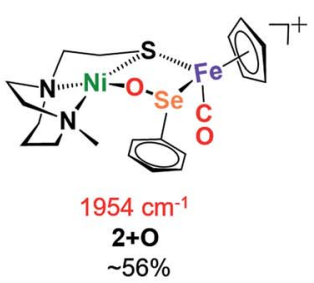
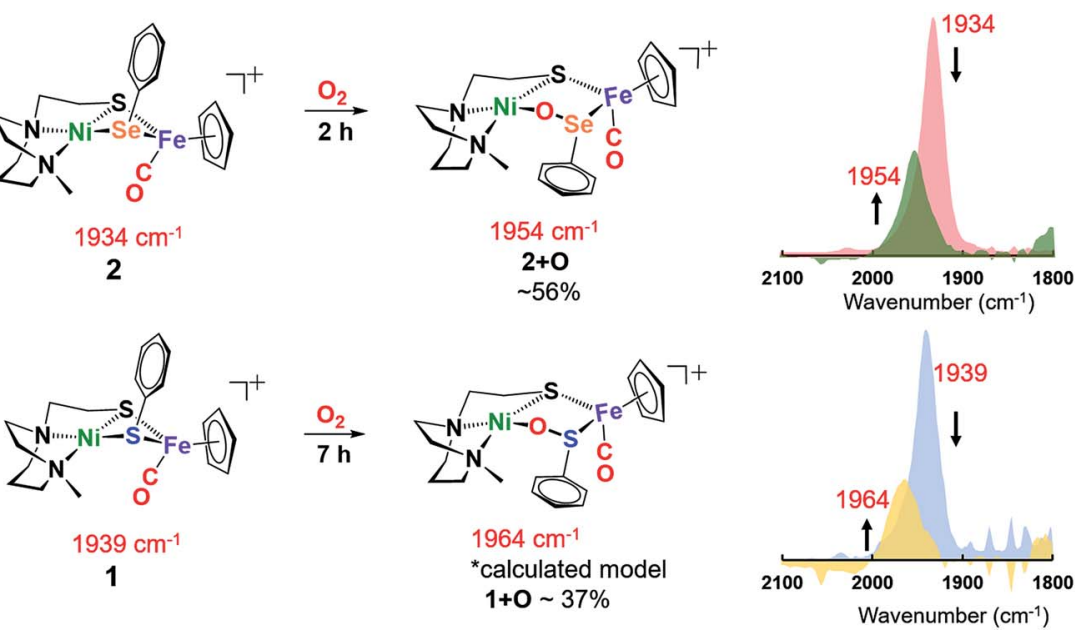

Fig. 4 Reactions of 1 and 2 in the presence of 1 atm $\mathrm{O}_{2}$ in $\mathrm{CH}_{2} \mathrm{Cl}_{2}$ at $22{ }^{\circ} \mathrm{C}$; conversions determined by $\nu(\mathrm{CO})$ analysis. 
residue, which was soluble in $\mathrm{CH}_{3} \mathrm{CN}$, was confirmed as the $\left[\mathrm{NiN}_{2} \mathrm{~S}\right]_{2}{ }^{2+}$ dimer by XRD with crystals obtained by ether diffusion; it was isolated in $35 \%$ yield. A remaining insoluble yellow solid was found to be an iron(III) oxide complex (see ESI †). Reactions performed in air instead of pure $\mathrm{O}_{2}$ yielded (more slowly) the same products.

The $\mathrm{O}_{2}$-bubbled $\mathrm{CH}_{2} \mathrm{Cl}_{2}$ solution of the all-sulfur analogue $\mathrm{NiS}_{\mathrm{Ph}} \mathrm{Fe}^{+}, 1$, required $7 \mathrm{~h}$ to completion, indicated by the decrease in IR absorption at $\nu(\mathrm{CO}) 1939 \mathrm{~cm}^{-1}$ as the oxidized species appeared as a broad band at $\nu$ (CO) $1964 \mathrm{~cm}^{-1}$ (Fig. 4). The reactivity (time) difference is consistent with the fact that $\mathrm{S}^{2-}$ is oxidized with more difficulty than $\mathrm{Se}^{2-} .7$ The high resolution ESI-MS ${ }^{+}$of products from 1 and $\mathrm{O}_{2}$ in $\mathrm{CH}_{3} \mathrm{CN}$ indicated the uptake of one, two, and three oxygens (Fig. S19†). Based on DFT calculations (vide infra), complex $\mathbf{1}+\mathbf{O}$ is of a similar structure as $\mathbf{2 + O}$. Both $\mathbf{1 + O}$ and $\mathbf{2 + O}$ show sharp signals in their NMR spectra and are EPR-silent, indicating that $\mathrm{Ni}$ and Fe are low spin, +2 species (Fig. S30, S31 and S38 + ). To confirm that the $\mathbf{1}+\mathbf{O}$ and $2+\mathbf{O}$ were derived from molecular $\mathrm{O}_{2}$, the same reactions were carried out with added ${ }^{18} \mathrm{O}_{2}$. Mass spectral analysis indicated the uptake of labelled O-18, Fig. S43 and S44. $\dagger$

Crystals of complex $\mathbf{2}+\mathbf{O}$ were obtained by layering pentane on DCM solutions of $\mathbf{2 + 0}$. As seen in Fig. 5, complex $2+\mathbf{O}$ contains a 5-membered, puckered NiOSeFeS ring; the Ni(II) is the center of a square planar $\mathrm{N}_{2} \mathrm{SO}$ binding site. From XRD the bond distances of $\mathrm{Ni}-\mathrm{S}$ and $\mathrm{Fe}-\mathrm{S}$ in $\mathbf{2 + O}$ are largely the same as in the reduced form 2 (or $\mathbf{2}^{\prime}$ ); the oxygen insertion into the $\mathrm{Ni}-\mathrm{Se}$ bond results in an $\mathrm{Ni}-\mathrm{O}$ bond at 1.870(2) $\AA$. The Fe-Se bond length becomes slightly shorter in $\mathbf{2 + O}, 2.333(1) \AA$, as compared to 2, 2.406(1) $\AA$. The distance between $\mathrm{Ni}$ and $\mathrm{Fe}$ in $2+\mathrm{O}$ is 3.568 $\AA$, ca. $0.3 \AA$ longer than in the reduced form, reflecting the expansion of the ring. Note that the Ni-A form of the [NiFe]$\mathrm{H}_{2}$ ase enzyme active site with sulfenate also has a 5-membered

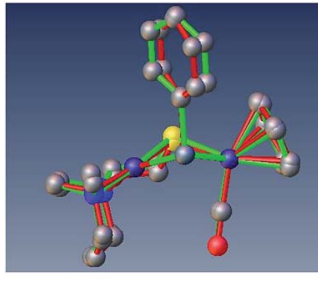

2 Exp. 2 Calc.

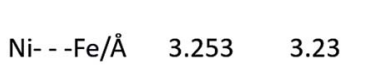

$\mathrm{Ni}-\mathrm{Se} / \mathrm{A} \quad 2.311(1) \quad 2.338$

$\mathrm{Fe}-\mathrm{Se} / \AA ̊ \AA \quad 2.406(1) \quad 2.439$

$\mathrm{Ni}-\mathrm{Se}-\mathrm{Fe} /{ }^{\circ} \quad 87.17(4) \quad 85.15$

Hinge/ ${ }^{\circ} \quad 142.69 \quad 136.77$
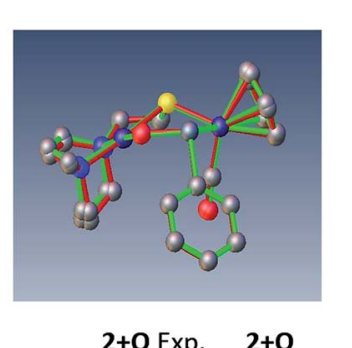

2+0

Calc.

$\mathrm{Ni}-\mathrm{Fe} / \AA ̊ \AA \quad 3.568 \quad 3.615$

$\mathrm{Ni}-\mathrm{Se} / \AA ̊ \AA \quad 3.168 \quad 3.209$

$\mathrm{Ni}-\mathrm{S} / \mathrm{A} \quad 2.153(1) \quad 2.175$

$\mathrm{Ni}-\mathrm{O} / \AA ̊ A \quad 1.870(2) \quad 1.869$

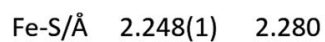

Fe-Se/Å 2.333(1) 2.336

O-Ni-S/ ${ }^{\circ}$ 92.93(7) 93.05

Se-Fe-S/ ${ }^{\circ} \quad 86.15(3) \quad 86.22$

Fig. 5 Overlay of experimental and computational structures of 2 and $2+\mathrm{O}$ along with selected geometric parameters. Hydrogens deleted for clarity.
NiOSFeS ring, Fig. $1 .^{24}$ The Ni $\cdots \mathrm{O}$ distance in Ni-A is $1.824 \AA$, while in 2+O it is 1.870 (2) $\AA$. In contrast, a minor fraction from [NiFeSe] $-\mathrm{H}_{2}$ ase oxidation reported by Volbeda et al. has a different connectivity, NiSeOFe, Fig. $1 .{ }^{9}$ Complex $2+0$ is, to our knowledge, the first model of an oxygenated [NiFeSe]- $\mathrm{H}_{2}$ ase synthetic analogue derived from direct reaction.

As a comparison to the $\mathrm{NiE}_{\mathrm{Ph}} \mathrm{Fe}$ complexes 1 and 2, constrained $\mathrm{NiN}_{2} \mathrm{~S}_{2}$ derivatives, $\left[\mathrm{NiN}_{2} \mathrm{~S}_{2} \cdot \mathrm{Fe}\left(\eta^{5}-\mathrm{C}_{5} \mathrm{H}_{5}\right)(\mathrm{CO})\right]^{+}\left[\mathrm{BF}_{4}\right]^{-}$ and $\left[\mathrm{NiN}_{2} \mathrm{~S}_{2} \cdot \mathrm{Fe}\left(\eta^{5}-\mathrm{C}_{5} \mathrm{Me}_{5}\right)(\mathrm{CO})\right]^{+}\left[\mathrm{BF}_{4}\right]^{-} \mathrm{N}_{2} \mathrm{~S}_{2}=$ bismercaptoethanediazacycloheptane) were tested for reactivity with oxygen. ${ }^{25,26}$ After stirring their solutions in an $\mathrm{O}_{2}$ atmosphere for several days, they remain intact with no indication of reaction. We surmise that the $\mathrm{CO}$ which is bound to Fe prevents $\mathrm{O}_{2}$ activation at the $\mathrm{Fe}$ center and both sulfur and nickel are deactivated towards $\mathrm{O}_{2}$ reactivity in the rigid chelating $\mathrm{N}_{2} \mathrm{~S}_{2}$ ligands. However, in complexes 1 and 2, the mobility at EPh $\left(\mathrm{E}=\mathrm{S}\right.$ or $\mathrm{Se}$ ) provides a potential site for $\mathrm{O}_{2}$ attack on the $\mathrm{Ni}$ or Fe, consistent with the splitting of 1 and 2 by $\mathrm{CO}(\mathrm{g})$ (Fig. S33†). For comparison, elevated temperature $\left(70{ }^{\circ} \mathrm{C}\right)$ and 11 bar $\mathrm{CO}(\mathrm{g})$ are required to break one $\mathrm{Ni}-\mathrm{S}$ bond in $\left[\mathrm{NiN}_{2} \mathrm{~S}_{2} \cdot \mathrm{Fe}\left(\eta^{5}\right.\right.$ $\left.\left.\mathrm{C}_{5} \mathrm{H}_{5}\right)(\mathrm{CO})\right]^{+}\left[\mathrm{BF}_{4}\right]^{-.25}$

\section{Computational section}

The crystal structures of $\mathbf{2}$ and $\mathbf{2}+\mathbf{O}$ were used as geometric starting points for DFT calculations (TPSSTPSS functional with the $6-311++G(d, p)$ basis set on all nonmetal atoms and the 6$311+\mathrm{G}$ basis set for $\mathrm{Ni}$ and $\mathrm{Fe}$ atoms) and then optimized using the Gaussian 09 program using the SMD implicit solvation model with acetonitrile as the solvent. ${ }^{28}$ Cartesian coordinates of calculated structures are given in the ESI. $\dagger$ The calculated structures for $\mathbf{2}$ and $\mathbf{2}+\mathbf{O}$ showed excellent agreement with the corresponding experimental structures, Fig. 5. Similar structures were found for the sulfur analogues, $\mathbf{1}$ and $\mathbf{1 + 0}$.

The structure of $\mathbf{2 + 0}$ was investigated to determine contributing factors to the thermodynamically favored oxygenation product. A less rigid model of $2+\mathbf{O}$ was made by breaking

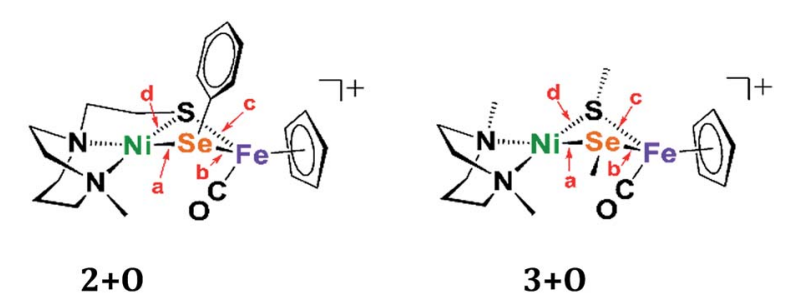

\begin{tabular}{|c|c|c|c|c|}
\hline & $\mathbf{a}$ & $\mathbf{b}$ & $\mathbf{c}$ & $\mathbf{d}$ \\
\hline $\mathbf{2 + 0}$ & 0 & +8.6 & +10.0 & +15.5 \\
\hline $\mathbf{3 + 0}$ & +3.2 & +10.0 & +14.2 & 0 \\
\hline
\end{tabular}

Fig. 6 Relative energies of oxygenated isomers of $\mathrm{N}_{2} \mathrm{SSe}_{\mathrm{Ph}}$ model,

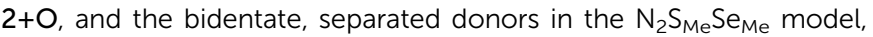
$3+\mathrm{O}$, in $\mathrm{kcal} \mathrm{mol}^{-1}$. A range of functionals and basis sets were explored and found to elicit minor differences on energies of complexes but do not change the ordering of isomers' energies (Fig. S41 $\dagger$ ). 


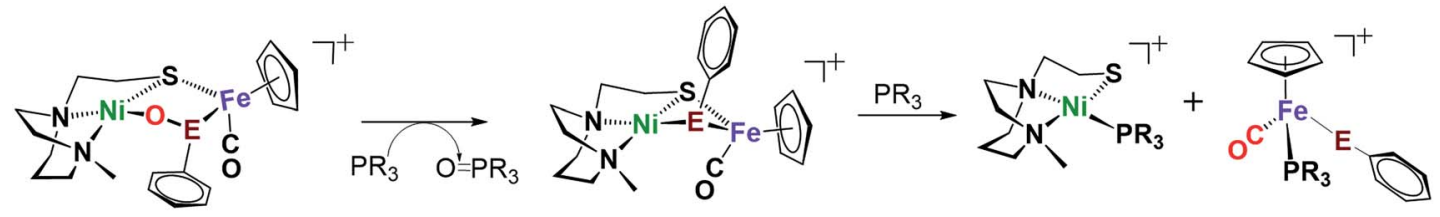

Fig. 7 Reaction of complex $2+\mathrm{O}(\mathrm{E}=\mathrm{Se})$ or $1+\mathrm{O}(\mathrm{E}=\mathrm{S})$ with $\mathrm{O}$-abstracting agents, $\mathrm{PR}_{3}(\mathrm{R}=\mathrm{Me}$ or $\mathrm{O}$-tolyl).

the carbon-carbon bond linking the sulfur donor to the neighbouring nitrogen donor, changing the resulting methylene fragments into methyl groups, and replacing the phenyl group on Se-Ph with a methyl group. This bidentate $\mathrm{N}_{2} \mathrm{~S}_{\mathrm{Me}} \mathrm{Se}_{\mathrm{Me}}$ model, with unconnected SMe, is designated as $\mathbf{3}$ and is designed to create similar electronic, steric environments and constraints around the sulfur and selenium atoms.

Four oxygenated isomers, $\mathbf{3}+\mathbf{O}_{\mathbf{a}-\mathbf{d}}$, as well as four corresponding isomers, $\mathbf{2}+\mathbf{O}_{\mathbf{a}-\mathbf{d}}$, were calculated in which the location of the oxygen atom was varied according to the scheme described in Fig. 6. The isomer $\mathbf{2}+\mathbf{O}_{\mathbf{a}}$, which corresponds to the experimental structure, is indeed the lowest energy isomer of $\mathbf{2 + O}$; the next lowest isomer, $\mathbf{2}+\mathbf{O}_{\mathbf{b}}$, is $8.6 \mathrm{kcal}$ higher in energy. This contrasts with the $\mathrm{N}_{2} \mathrm{~S}_{\mathrm{Me}} \mathrm{Se}_{\mathrm{Me}}$ model in which the lowest energy isomer, $\mathbf{3}_{\mathbf{d}}$, has the oxygen atom inserted between the nickel and the sulfur atoms rather than the nickel and selenium. The corresponding isomer $\mathbf{2}+\mathbf{O}_{\mathbf{d}}$ is the highest energy isomer for the tridentate model and the oxygen atom appears in a position bridging the nickel sulfur bond rather than full insertion. This is likely due to the geometric restraints imposed by the tridentate $\mathrm{N}_{2} \mathrm{~S}$ ligand that disfavor the addition of the oxygen atom into its rigid binding arrangement. This constraint is not found in the more open bidentate model with separated SMe donors. There it is found that formation of a sulfur-oxygen bond is thermodynamically favored, by $3.2 \mathrm{kcal} \mathrm{mol}^{-1}$, as compared to the formation of a selenium-oxygen bond.

\section{O-atom removal results}

As arbiters between $\mathrm{O}_{2}$ and the $[\mathrm{NiFe}]$ or $[\mathrm{NiFeSe}]-\mathrm{H}_{2}$ ase active sites, chalcogenides prevent complete degradation of the organometallic active sites of hydrogenases, and perform this role reversably. ${ }^{24,27}$ To explore the possibility of reversal of oxygenated selenate/sulfenate, $\mathrm{O}$-abstracting agents, $\mathrm{PR}_{3}(\mathrm{R}=$ Me or $o$-tolyl), were employed for O-atom removal (Fig. 7). The $\nu$ (CO) monitor of the reaction of $2+\mathbf{O}$ and 1 equiv. of $\mathrm{PMe}_{3}$ in DCM showed a band shift from 1954 to $1934 \mathrm{~cm}^{-1}$. The latter absorption is made up from a mixture of complex 2 and the $\mathrm{PMe}_{3}$ species $\left(\eta^{5}-\mathrm{C}_{5} \mathrm{H}_{5}\right) \mathrm{Fe}(\mathrm{SePh})\left(\mathrm{PMe}_{3}\right)(\mathrm{CO})$, which is confirmed by the ${ }^{+}$ESI-MS data (Fig. S37 $\dagger$ ). The reaction of a mixture of $\mathbf{1 + O}$ and $1+2 \mathrm{O}$ with 1 equiv. of $\mathrm{PMe}_{3}$ resulted in partial conversion of $1+O$ to 1 , finding that $1+2 O$ was unchanged, even in presence of excess $\mathrm{PMe}_{3}$. The ${ }^{+}$ESI-MS (Fig. S36†) indicates the formation of reduced complex 2, unreacted $\mathbf{1 + 2 O}$ and the $\mathrm{PMe}_{3}$ derivative $\left(\eta^{5}-\mathrm{C}_{5} \mathrm{H}_{5}\right) \mathrm{Fe}(\mathrm{SPh})\left(\mathrm{PMe}_{3}\right)(\mathrm{CO})$. Removal of the O-atom from 1+O and $2+\mathbf{O}$ by reducing agents containing $\mathrm{H}^{-}$, as well as electrochemically $\left(\mathrm{e}^{-}+\mathrm{H}^{+}\right)$, have thus far been unsuccessful.

\section{Conclusion}

In summary, we have observed oxygenation and O-atom removal from two biomimetic complexes with features of the $[\mathrm{NiFeS}] /[\mathrm{NiFeSe}]-\mathrm{H}_{2}$ ase active sites. Our study highlights the usefulness of the $\left[\mathrm{NiN}_{2} \mathrm{~S}\right]_{2}{ }^{2+}$ synthetic platform for generating NiFe biomimetic complexes. Clearly the $\mathrm{NiE}_{\mathrm{Ph}} \mathrm{Fe}^{+}$complex differs from the active site of [NiFeSe]- $\mathrm{H}_{2}$ ase as the selenium in the model is in a bridging position, rather than terminal as nature has adopted. The relative reactivities however are consistent with what is found in nature. As compared to complex $\mathbf{1}$, the selenium-bridged complex 2 required a shorter time to generate oxygenated selenium, 2+o. The partial conversion of oxygenated chalcogenides (Se or S oxidation states of 0 ) back to reduced $\mathrm{S} / \mathrm{Se}$ (oxidation state -2 ) in this study provides a foundation for the mechanism of reactivation of $\mathrm{S} / \mathrm{Se}$-oxygenated [NiFeE] $-\mathrm{H}_{2}$ ases. Oxygen-uptake by $\mathrm{S} / \mathrm{Se}$ in [NiFeS]- and [ $\mathrm{NiFeSe}]-\mathrm{H}_{2}$ ases results in modification of the active site, but less severe than would result in irreparable degradation. ${ }^{27}$ During the oxygenation and O-atom removal from the chalcogen atom, we note that the mobility in the Ni-E bond plays a vital role.

The variety of oxygenates thus far found in nature, Fig. 1, speak to the ability of the chalcogens to maintain a close attachment to the NiFe site. Detailed $\mathrm{O}_{2} / \mathrm{H}_{2}$ ase active site reaction mechanisms remain obscure but of great interest. ${ }^{29,30}$ Our studies of model complexes point to the possibility of opening the Ni-E bond in the $\mathrm{Ni}-\left(\mu \mathrm{E}_{\mathrm{Ph}}\right)-\mathrm{Fe}$ unit. Such bond cleavage exposes a reactive lone pair on sulfur or selenium that attracts the electrophilic $\mathrm{O}_{2}$ molecule concomitant with providing an open site on $\mathrm{Ni}^{2+}$ for assisted activation, leading to the product. A related strategy for protection of the active site from oxidative damage is seen in the MBH (membrane-bound respiratory [NiFeS]-hydrogenase) wherein the proximal [4Fe-3S] cluster donates two electrons and one proton for reduction of adventitious $\mathrm{O}_{2}{ }^{31}$

\section{Conflicts of interest}

There are no conflicts to declare.

\section{Acknowledgements}

This work was funded by the National Science Foundation (CHE-1300787, CHE-1664866 to M. B. H. and CHE-1266097, CHE-1665258 to M. Y. D.) and the Robert A. Welch Foundation (A-0648 to M. B. H. and A-0924 to M. Y. D.). 


\section{Notes and references}

1 W. Lubitz, H. Ogata, O. Rudiger and E. Reijerse, Chem. Rev., 2014, 114, 4081.

2 L. L. Beer, E. S. Boyd, J. W. Peters and M. C. Posewitz, Curr. Opin. Biotechnol., 2009, 20, 264.

3 M. Hambourger, M. Gervaldo, D. Svedruzic, P. W. King, D. Gust, M. Ghirardi, A. L. Moore and T. A. Moore, J. Am. Chem. Soc., 2008, 130, 2015.

4 C. S. A. Baltazar, M. C. Marques, C. M. Soares, A. M. DeLacey, I. A. C. Pereira and P. M. Matias, Eur. J. Inorg. Chem., 2011, 948.

5 D. W. Wakerley and E. Reisner, Energy Environ. Sci., 2015, 8, 2283.

6 P. M. Vignais and B. Billoud, Chem. Rev., 2007, 107, 4206.

7 H. J. Reich and R. J. Hondal, ACS Chem. Biol., 2016, 11, 821.

8 M. C. Marques, R. Coelho, A. L. De Lacey, I. A. Pereira and P. M. Matias, J. Mol. Biol., 2010, 396, 893.

9 A. Volbeda, P. Amara, M. Iannello, A. L. De Lacey, C. Cavazza and J. C. Fontecilla-Camps, Chem. Commun., 2013, 49, 7061.

10 M. Horch, L. Lauterbach, M. A. Mroginski, P. Hildebrandt, O. Lenz and I. Zebger, J. Am. Chem. Soc., 2015, 137, 2555.

11 H. Ogata, W. Lubitz and Y. Higuchi, Dalton Trans., 2009, 7577.

12 M. Isegawa, A. K. Sharma, S. Ogo and K. Morokuma, Organometallics, 2018, 37, 1534.

13 T. Kishima, T. Matsumoto, H. Nakai, S. Hayami, T. Ohta and S. Ogo, Angew. Chem., Int. Ed., 2016, 55, 724.

14 T. Matsumoto, T. Kishima, T. Yatabe, K.-S. Yoon and S. Ogo, Organometallics, 2017, 36, 3883.

15 E. Garcin, X. Vernede, E. Hatchikian, A. Volbeda, M. Frey and J. Fontecilla-Camps, Structure, 1999, 7, 557.

16 A. Volbeda, M.-H. Charon, C. Piras, E. C. Hatchikian, M. Frey and J. C. Fontecilla-Camps, Nature, 1995, 373, 580.

17 C. A. Grapperhaus and M. Y. Darensbourg, Acc. Chem. Res., 1998, 31, 451.

18 N. J. Lindenmaier, S. Wahlefeld, E. Bill, T. Szilvasi, C. Eberle, S. Yao, P. Hildebrandt, M. Horch, I. Zebger and M. Driess, Angew. Chem., Int. Ed., 2017, 56, 2208.

19 J. A. Denny and M. Y. Darensbourg, Chem. Rev., 2015, 115, 5248.

20 R. M. Jenkins, M. L. Singleton, L. A. Leamer, J. H. Reibenspies and M. Y. Darensbourg, Inorg. Chem., 2010, 49, 5503.
21 E. M. Gale, D. M. Cowart, R. A. Scott and T. C. Harrop, Inorg. Chem., 2011, 50, 10460.

22 D. Huang, L. Deng, J. Sun and R. H. Holm, Inorg. Chem., 2009, 48, 6159.

23 D. Brazzolotto, M. Gennari, N. Queyriaux, T. R. Simmons, J. Pecaut, S. Demeshko, F. Meyer, M. Orio, V. Artero and C. Duboc, Nat. Chem., 2016, 8, 1054.

24 A. Volbeda, L. Martin, E. Barbier, O. Gutiérrez-Sanz, A. L. D. Lacey, P.-P. Liebgott, S. b. Dementin, M. Rousset and J. C. Fontecilla-Camps, J. Biol. Inorg Chem., 2014, 20, 11.

25 S. Ding, P. Ghosh, A. M. Lunsford, N. Wang, N. Bhuvanesh, M. B. Hall and M. Y. Darensbourg, J. Am. Chem. Soc., 2016, 138, 12920.

26 P. Ghosh, M. Quiroz, N. Wang, N. Bhuvanesh and M. Y. Darensbourg, Dalton Trans., 2017, 46, 5617.

27 K. A. Vincent, A. Parkin, O. Lenz, S. P. J. Albracht, J. C. Fontecilla-Camps, R. Cammack, B. Friedrich and F. A. Armstrong, J. Am. Chem. Soc., 2005, 127, 18179.

28 M. J. Frisch; G. W. Trucks; H. B. Schlegel; G. E. Scuseria; M. A. Robb; J. R. Cheeseman; G. Scalmani;V. Barone; B. Mennucci; G. A. Petersson; H. Nakatsuji; M. Caricato; X. Li; H. P. Hratchian; A. F. Izmaylov; J. Bloino; G. Zheng; J. L. Sonnenberg; M. Hada; M. Ehara; K. Toyota; R. Fukuda; J. Hasegawa; M. Ishida; T. Nakajima; Y. Honda; O. Kitao; H. Nakai; T. Vreven; J. A. Montgomery Jr; J. E. Peralta; F. Ogliaro; M. Bearpark; J. J. Heyd; E. Brothers; K. N. Kudin; V. N. Staroverov; R. Kobayashi; J. Normand; K. Raghavachari; A. Rendell; J. C. Burant; S. S. Iyengar; J. Tomasi; M. Cossi; N. Rega; J. M. Millam; M. Klene; J. E. Knox; J. B. Cross; V. Bakken; C. Adamo; J. Jaramillo; R. Gomperts; R. E. Stratmann; O. Yazyev; A. J. Austin; R. Cammi; C. Pomelli; J. W. Ochterski; R. L. Martin; K. Morokuma; V. G. Zakrzewski; G. A. Voth; P. Salvador; J. J. Dannenberg; S. Dapprich; A. D. Daniels;

O. Farkas; J. B. Foresman; J. V. Ortiz; J. Cioslowski; D. J. Fox, Gaussian 09, revision D.01, Gaussian, Inc., Wallingford, CT, 2009.

29 S. Ogo, Coord. Chem. Rev., 2017, 334, 43.

30 S. Ogo, Chem. Rec., 2014, 14, 397.

31 Y. Shomura, K. S. Yoon, H. Nishihara and Y. Higuchi, Nature, 2011, 479, 253. 